\title{
Edukasi Penerapan Pola Hidup Bersih dan Sehat (PHBS) Sebagai Upaya Pencegahan Covid-19 di Dusun Tegalrejo, Kelurahan Begajah, Kecamatan Sukoharjo
}

\author{
Aprilia Nur Arninasari $^{1}$, Valiant Lukad Perdana Sutrisno ${ }^{2}$ \\ ${ }^{1}$ Office Administration Education The Faculty of Teacher Training and Education Sebelas Maret \\ University Indonesia \\ ${ }^{2}$ Mechanical Engineering Education The Faculty of Teacher Training and Education Sebelas \\ Maret University Indonesia \\ Corresponding email: arninaaprilia@gmail.com
}

\begin{abstract}
Clean and Healthy Lifestyle (PHBS) are all health behaviors that are carried out because of personal awareness so that families and all members are able to help themselves in the health sector and have an active role in community activities. The clean and healthy lifestyle during the Covid-19 pandemic has very influential benefits to change life habits that are even better and can protect oneself to avoid Covid-19 so that education on the application of a clean and healthy lifestyle can increase public understanding regarding the application. a clean and healthy lifestyle such as using masks, washing hands, and using hand sanitizers. This education is carried out directly by distributing masks and hand sanitizers and through printed media such as mmt and pamphlets around RT 01 / RW 04, Begajah Village while adhering to health protocols. This education was carried out as a real Covid-19 work course work program.
\end{abstract}

Keywords: Education; Covid-19; Pandemic; Health protocols; PHBS.

\begin{abstract}
ABSTRAK
Pola Hidup Bersih dan Sehat (PHBS) merupakan semua perilaku kesehatan yang dilakukan karena kesadaran pribadi sehingga keluarga dan seluruh anggotanya mampu menolong diri sendiri pada bidang kesehatan serta memiliki peran aktif dalam aktivitas masyarakat. Perilaku hidup bersih sehat pada masa pandemi Covid-19 memiliki manfaat yang sangat berpengaruh untuk mengubah kebiasaan hidup yang semakin lebih baik lagi dan dapat melindungi diri agar terhidar dari Covid-19 sehingga dengan adanya edukasi penerapan pola hidup bersih dan sehat dapat menambah pemahaman masyarakat terkait penerapan pola hidup bersih dan sehat seperti menggunakan masker, mencuci tangan, dan penggunaan hand sanitizer. Edukasi ini dilakukan secara langsung dengan membagikan masker dan hand sanitizer serta melalui media cetak seperti mmt maupun pamflet di dekitar RT 01 / RW 04, Desa Begajah dengan tetap mematuhi protokol kesehatan. Edukasi ini dilalukan sebagai program kerja kuliah kerja nyata (KKN) Covid-19.
\end{abstract}

Kata kunci: kata kuncinya; terdiri dari lima frase; dipisahkan dengan titik koma. 


\section{PENDAHULUAN}

Coronavirus Diseases 2019 (COVID-19) merupakan suatu penyakit yang disebabkan oleh strain coronavirus baru (SARS-CoV-2) yang muncul di Wuhan, Hubei, Cina pada Desember 2019. Penyakit ini sebelumnya dikenal dengan sebutan 2019 novel coronavirus (2019-nCoV) (WHO, 2020c). Penggunaan istilah COVID-19 diresmikan oleh WHO pada tanggal 11 Februari 2020 (WHO, 2020f). Covid-19 ini dapat menimbulkan gejala gangguan pernafasan akut seperti demam diatas $38^{\circ} \mathrm{C}$, batuk dan sesak nafas bagi manusia. Selain itu dapat disertai dengan lemas, nyeri otot, dan diare. Pada penderita COVID-19 yang berat, dapat menimbulkan pneumonia, sindroma pernafasan akut, gagal ginjal bahkan sampai kematian. Covid-19 dapat menular dari manusia ke manusia melalui kontak dan droplet (percikan cairan pada saat bersin dan batuk), tidak melalui udara. Bentuk COVID-19 jika dilihat melalui mikroskop elektron (cairan saluran nafas) dan digambarkan kembali bentuk COVID-19 seperti virus yang memiliki mahkota. Saat ini COVID-19 sudah menjadi pandemi, artinya terjadi penambahan kasus penyakit yang cukup cepat dan sudah terjadi penyebaran antar negara (Susilo et al).

Adanya Pandemi Covid-19 ini berdampak pada kehidupan masyarakat yang dapat dikatakan banyak sekali perubahan seperti yang awal mulanya kita bebas kemana saja tanpa menggunakan masker harus menggunakan masker dan mematuhi protokol kesehatan yang berlaku demi mencegah penyebaran virus Covid-19, selain itu kegiatan semula yang bisa dilakukan secara offline sekarang banyak kegiatan yang dialihkan secara online. Dampak tersebut dirasakan oleh seluruh lapisan masyarakat mulai dari para pegawai, mahasiswa, wirausaha, dll. Salah satunya seperti kegiatan rutin mahasiswa yaitu Kuliah Kerja Nyata (KKN) sebagai kegiatan wajib yang harus diikuti oleh mahasiswa di semester akhir sebagai bentuk pengabdian mahasiswa kepada masyarakat tempat dilaksanakannya kegiatan tersebut. Dengan adanya pandemi Covid-19 kegiatatan KKN mahasiswa dialihkan menjadi KKN Covid-19 yang mana setiap mahasiswa menjadi relawan di daerah tempat tinggal masing-masing mahasiswa. 
Beberapa langkah efektif dapat dilakukan untuk mencegah penyebaran COVID-19. Selain social distancing dan isolasi mandiri, penerapan PHBS juga mampu meminimalisir kemungkinan terpapar virus. Perilaku hidup bersih dan sehat pada saat masa pandemic dapat diterapkan dengan berbagai cara antara lain dengan membiasakan diri mencuci tangan, setiap sebelum dan sesudah beraktivitas, memakai masker, menjaga lingkungan, mengonsumsi makanan yang bergizi, serta olahraga. Perilaku hidup bersih dan sehat ini bertujuan untuk lebih menyadarkan diri kita sendiri akan pentingnya menjaga kesehatan. Upaya-upaya PHBS tersebut tentu harus disertai dengan asupan gizi seimbang dan aktif berolahraga agar daya tahan tubuh meningkat. Apabila sedang sakit, sebaiknya menerapkan etika batuk dan bersin, yakni menjauhi keramaian, serta menutup mulut dan hidung menggunakan tisu atau lipatan siku. Setelahnya, tisu dibuang ke tempat sampah tertutup. Penggunaan masker juga dilakukan baik bagi orang yang sedang sakit maupun yang sehat, untuk meminimalisasi penyebaran virus COVID-19. Penerapan PHBS di masyarakat juga mampu menciptakan lingkungan yang sehat dan meningkatkan kualitas hidup (Kementerian PUPR RI, 2020).

Kuliah Kerja Nyata $(\mathrm{KKN})$ merupakan kegiatan intrakulikuler yang memadukan pelaksanaan Tri Dharma Perguruan Tinggi dengan metode pemberian pengalaman belajar dan bekerja kepada mahasiswa dalam kegiatan pemberdayaan masyarakat. Salah satu kegiatan yang menambah daya kritis dan pengalaman bagi mahasiswa dalam bentuk nyata yaitu melalui kegiatan Kuliah Kerja Nyata. Tujuan utama KKN diarahkan kepada 3 aspek utama yang meliputi pengembangan kepribadian mahasiswa, pengembangan kelembagaan dan pengembangan masyarakat (Hardjasoemantri, 1997).

1. Agar perguruan tinggi menghasilkan sarjana sebagai penerus pembangunan yang lebih menghayati permasalahan yang sangat kompleks yang dihadapi masyarakat dalam pembangunan dan belajar menanggulangi permasalahan tersebut secara pragmatis dan interdisipliner. Hal ini erat kaitannya dengan pengembangan kepribadian mahasiswa (personality development). 
2. Untuk lebih mendekatkan perguruan tinggi kepada masyarakat, dan lebih menyesuaikan keberadaan pendidikan tinggi kepada tuntutan pembangunan (institutional development).

3. Membantu pemerintah dalam percepatan laju pembangunan dan mempersiapkan kader-kader pembangunan di pedesaan (community development).

Dusun Tegalrejo, Kelurahan Behgajah, Kecamatan Sukoharjo memiliki masyarakat yang sebagian besar merupakan pekerja kantoran dan wirausaha, serta terdapat masyarakat yang berlanjut usia. Bagi para pekerja mungkin sudah memahami apa itu penerapan pola hidup bersih dan sehat, akan tetapi bagi masyarakat yang memiliki usaha sendiri di rumah masih belum memiliki kesadaran dalam penerapan pola hidup bersih dan sehat seperti halnya dalam pemakaian masker yang masih jarang ditemui. Oleh karena itu dengan adanya program Kuliah Kerja Nyata (KKN) di dusun tegalrejo diharapkan dapat memberi pemahaman dan menyadarkan masyarakat akan pentingnya pola hidup bersih dan sehat terutama dalam masa pandemic covid-19 seperti sekarang ini.

\section{TINJAUAN PUSTAKA}

\section{Covid-19}

Coronavirus adalah virus RNA besar beruntai tunggal positif yang terselubung yang menginfeksi manusia, tetapi juga berbagai macam hewan. Coronavirus pertama kali dijelaskan pada tahun 1966 oleh Tyrell dan Bynoe, yang dibudidayakan virus dari pasien dengan demam biasa (Bynoe,Tyrell,1996). Berdasarkan morfologinya sebagai virion bulat dengan cangkang inti dan proyeksi permukaan menyerupai korona matahari, mereka disebut coronavirus (bahasa Latin: corona $=$ mahkota). Empat subfamili, yaitu alpha-, beta-, gamma- dan delta-coronavirus ada. Sementara alpha- dan betacoronavirus tampaknya berasal dari mamalia, khususnya dari kelelawar, gammadan delta-virus berasal dari babi dan burung. Ukuran genom bervariasi antara 26 $\mathrm{kb}$ dan $32 \mathrm{~kb}$. Di antara tujuh subtipe coronavirus yang dapat menginfeksi manusia, beta-coronavirus dapat menyebabkan penyakit parah dan kematian, 
sedangkan alpha-coronavirus menyebabkan infeksi tanpa gejala atau gejala ringan. SARS-CoV-2 termasuk dalam garis keturunan B dari beta-coronaviruses dan terkait erat dengan virus SARS-CoV.

Tanda klinis awal penyakit terkait SARS-CoV-2 COVID-19 yang memungkinkan deteksi kasus adalah pneumonia. Laporan yang lebih baru juga menggambarkan gejala gastrointestinal dan infeksi tanpa gejala, terutama di kalangan anak kecil (Chan JF, Yuan S, Kok KH,2019). Pengamatan sejauh ini menunjukkan masa inkubasi rata-rata lima hari dan masa inkubasi rata-rata 3 hari (kisaran: 0-24 hari). Proporsi individu yang terinfeksi oleh SARS-CoV-2 yang tetap asimtomatik selama perjalanan infeksi belum dinilai secara pasti. Pada pasien simtomatik, manifestasi klinis penyakit biasanya mulai setelah kurang dari seminggu, terdiri dari demam, batuk, hidung tersumbat, kelelahan, dan tandatanda infeksi saluran pernapasan atas lainnya. Infeksi dapat berkembang menjadi penyakit yang parah dengan dyspnoea dan gejala dada yang parah sesuai dengan pneumonia di sekitar $75 \%$ dari pasien, seperti yang terlihat oleh computed tomography. Pneumonia sebagian besar terjadi pada minggu kedua atau ketiga dari infeksi simtomatik. Tanda-tanda yang menonjol dari pneumonia virus termasuk penurunan saturasi oksigen, deviasi gas darah, perubahan yang terlihat melalui rontgen dada dan teknik pencitraan lainnya, dengan kelainan ground glass, konsolidasi yang tidak merata, eksudat alveolar dan keterlibatan interlobular, yang akhirnya menunjukkan perburukan. Limfopenia tampaknya umum, dan penanda inflamasi (protein C-reaktif dan sitokin proinflamasi) meningkat. (Guan W, Ni Z, Yu H,2019).

\section{Pola Hidup Bersih dan Sehat (PHBS)}

Perilaku Hidup Bersih dan Sehat (PHBS) adalah semua perilaku kesehatan yang dilakukan atas kesadaran sehingga anggota keluarga atau keluarga dapat menolong dirinya sendiri di bidang kesehatan dan dapat berperan aktif dalam kegiatan - kegiatan kesehatan dan berperan aktif dalam kegiatan-kegiatan kesehatan di masyarakat (Depkes RI, 2007). Pemberdayaan masyarakat harus dimulai dari rumah tangga atau keluarga, karena rumah tangga yang sehat merupakan asset atau modal pembangunan di masa depan yang perlu dijaga, 
ditingkatkan dan dilindungi kesehatannya. Beberapa anggota rumah tangga mempunyai masa rawan terkena penyakit menular dan penyakit tidak menular, oleh karena itu untuk mencegah penyakit tersebut, anggota rumah tangga perlu diberdayakan untuk melaksanakan PHBS.

\section{Kuliah Kerja Nyata}

Kuliah Kerja Nyata (KKN) pada dasarnya merupakan kegiatan interaksi sosial yang melibatkan berbagai pihak. Dalam kegiatan KKN, kita akan menjumpai berbagai bentuk interaksi sosial, yang secara garis besarnya dapat diklasifikasikan ke dalam tiga pola atau bentuk interaksi sosial, yaitu : (1) interaksi antar orang perorangan; (2) interaksi antara orang dan kelompoknya, dan sebaliknya; dan (3) Interaksi antar kelompok (Gunawan, 2000:32). Penyelenggaraan Kuliah Kerja Nyata diharapkan dapat menjangkau tiga sasaran utama. Pertama, sebagai wahana pembelajaran bagi para mahasiswa (peserta $\mathrm{KKN}$ ) untuk mengaplikasikan berbagai teori yang diperolehnya selama dalam perkuliahan, sesuai dengan disiplin ilmunya masingmasing.Kedua, Kuliah Kerja Nyata dapat memberikan nilai tambah dalam rangka meningkatkan kualitas kehidupan masyarakat. Ketiga, Kuliah Kerja Nyata merupakan media untuk membangun kemitraan antara lembaga perguruan tinggi yang bersangkutan dengan masyarakat, termasuk di dalamnya sebagai upaya untuk membangun citra sekaligus dapat dijadikan sebagai ajang promosi perguruan tinggi yang bersangkutan.

Kegiatan Kuliah Kerja Nyata adalah suatu bentuk pendidikan dengan cara memberikan pengalaman empiris kepada mahasiswa untuk hidup ditengahtengah masyarakat di luar kampus, dan secara langsung megajarkan kepada mahasiswa cara identifikasi masalah-masalah sosial yang terjadi di masyarakat. Kuliah kerja nyata secara langsung akan menunjukan keterkaitan langsung antara dunia pendidikan dan upaya perwujudan kesejahteraan masyarakat.

\section{METODOLOGI PENELITIAN}

Program KKN dilaksanakan oleh mahasiswa Universitas Sebelas Maret. Lokasi pelaksanaannya adalah Dusun Tegalrejo Rt 1 / Rw 4, Begajah, Sukoharjo, 
Provinsi Jawa Tengah. Kegiatan tersebut dimulai pada Bulan Oktober 2020. Dalam proses mendapatkan rumusan masalah, metode yang digunakan adalah dengan mengamati langsung kehidupan masyarakat pada saat pandemi. Setelah itu, mendefinisikan semua masalah yang muncul dan mencari solusinya bila diperlukan. Kemudian kami mencoba untuk mengidealkan solusi-solusi yang kami kumpulkan agar program-program yang dihasilkan dan dilaksanakan kedepannya dapat memberikan dampak yang signifikan bagi masyarakat Dusun Tegalrejo.

Kegiatan KKN ini dilakukan menggunakan metode kualitatif, yakni dengan melakukan wawancara kepada narasumber yang kompeten. Selanjutnya dilakukan kegiatan observasi dan dilanjutkan dengan studi kepustakaan oleh penulis. Setelah data terkumpul dilakukan analisis data untuk dapat mengetahui peranan kegiatan KKN yang dapat dilaksanakan sesuai dengan program kerja yang sudah disusun sehingga kegiatan pengabdian yang dilakukan mellaui kegiatan $\mathrm{KKN}$ dapat dipublikasikan dalam bentuk artikel.

Tabel 1. Kegiatan KKN

\begin{tabular}{llll}
\hline No. & \multicolumn{1}{c}{ Kegiatan } & \multicolumn{1}{c}{$\begin{array}{c}\text { Sasaran } \\
\text { Kegiatan }\end{array}$} & Keterangan \\
\hline 1. & Memberikan Pemahaman & Masyarakat & Dusun Begajah \\
kepada Masyarakat tentang & Dusun Tegalrejo, & \\
mencuci tangan melalui & Desa Begajah & \\
poster dan pemberian ember & & \\
cuci tangan
\end{tabular}

\begin{tabular}{llrl}
\hline 2. & $\begin{array}{l}\text { Pembagian Masker dan } \\
\text { Hansanitazier }\end{array}$ & $\begin{array}{l}\text { Masyarakat } \\
\text { Dusun Tegalrejo }\end{array}$ & $\begin{array}{l}\text { Mayoritas Pemilik toko } \\
\text { kelontong dan warung } \\
\text { makan }\end{array}$ \\
& & & \\
\hline 3. & $\begin{array}{l}\text { Membuat Video tutorial } \\
\text { pembuatan handsanitizer }\end{array}$ & Masyarakat & Dusun Tegalrejo \\
& &
\end{tabular}

Penelitian yang dilakukan oleh Denny (2020) pada masa pandemi dapat mewujudkan karakter masyarakat yang sadar akan kebersihan di lingkungannya. 
Kegiatan yang dilakukan mampu memberikan edukasi akan pentingnya menjaga kebersihan untuk memutus rantai penyebaran covid-19. Pengabdian ini dilakukan kepada masyarakat dalam mengimplementasikan ilmu yang diperoleh ketika di bangku perkuliahan.

\section{HASIL DAN PEMBAHASAN}

Program KKN masa pandemi dilakukan dengan tetap menerapkan protokol kesehatan yang ketat seperti menjaga jarak dan menggunakan masker sesuai dengan himbauan pemerintah.

Kegiatan pertama yang dilakukan selama KKN berlangsung yaitu memberikan edukasi tentang pemahaman mencuci tangan dengan baik dan benar serta memberikan ember cuci tangan di masjid dan toko kelontong sebagai penunjang program edukasi mencuci tangan di Dusun Tegalrejo Rt 1/Rw 4. Program tersebut bertujuan agar masyarakat senantiasa disiplin dalam mencuci tangan dan merupakan salah satu upaya yang paling efektif dalam mencegah tersebarnya virus-virus yang tidak terlihat dan bisa berasal dari mana saja. Selain itu program ini juga merupakan upaya dalam penerapan pola hidup bersih dan sehat di masa pandemic seperti sekarang ini yang dianjurkan oleh pemrintah. Dengan adanya penyediaan ember dan poster cuci tangan masyarakat Dusun Tegalrejo diharapkan dapat selalu ingat dalam mencuci tangan terlebih dahulu sebelum memasuki suatu tempat atau melalukan kegiatan apapun dan mencuci tangan dengan cara yang benar sesuai dengan atauran yang telah diberlakukan oleh pemerintah.
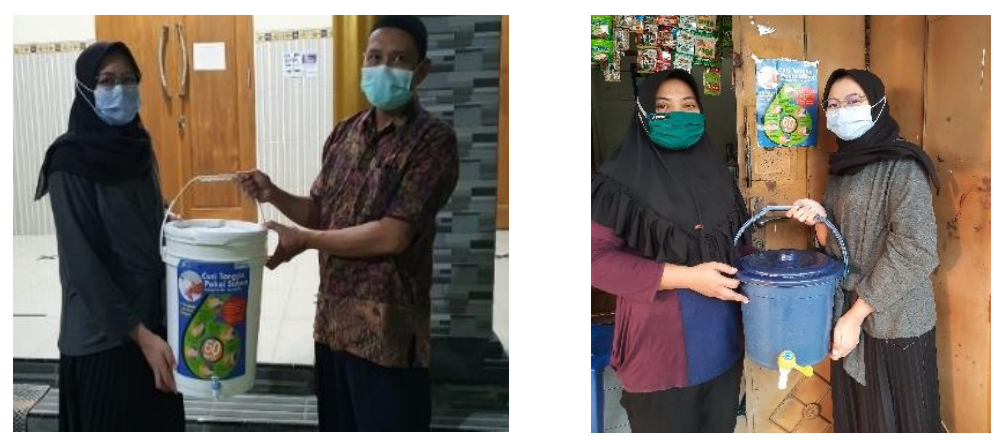

Gambar 1. Penyerahan Ember kepada Takmir Masjid Al-Huda dan Pemilik Toko Kelontong (Sumber : Dokumen Pribadi) 
Kegiatan kedua yang dilaksanakan adalah pembagian masker dan handsanitizer kepada masyarakat Dusun Tegalrejo. Program kerja yang dilaksanakan adalah mendistribusikan travel kit yang berisi masker kain dan handsanitizer kepada masyarakat sekitar. Mengingat virus Covid-19 mudah tertular melalui saluran pernafasan, dan droplet pemberian masker diharapkan dapat meningkatkan kesadaran masyarakat akan pentingnya penggunaan masker di masa sekarang ini. Selain itu, pembagian hansanitizer yang dapat digunakan sebagai pengganti air mengalir dengan bahan dasar alcohol dan aloevera yang mampu untuk membersihkan tangan dari virus yang tidak terlihat karena virus Covid-19 sendiri dapat berasal dari sentuhan atau tangan yang belum bersih. Dengan adanya program tersebut diharapkan masyarakat lebih disiplin dalam menggunakan masker terutama saat diluar rumah demi menjaga keselamatan diri sendiri maupun orang lain serta tidak beralasan lagi untuk tidak mencuci tangan karena terdapat handsanitizer sebagai alternatif untuk membersihkan tangan jika tidak menemukan atau mendapatkan air mrngalir dan sabun cuci tangan.

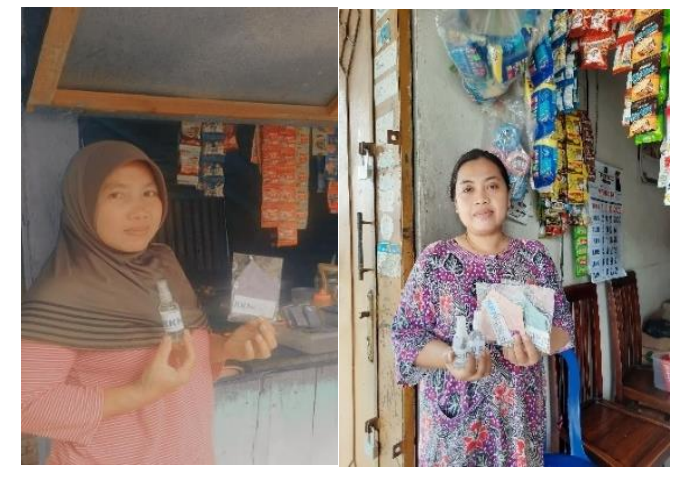

Gambar 2. Pembagian Masker dan Handsanitizer (Sumber : Dokumen Pribadi)

Kegiatan Ketiga yang dilaksanakan yaitu membuat video tutorial cara pembuatan handsanitizer. Pada masa pandemic sekarang ini hand sanitizer merupakan suatu hal wajib berada di dalam tas karena bisa berguna sebagai pengganti air mengalir untuk membersihkan tangan. Oleh karena itu pada kegiatan ini saya membuat video tentang pembuatan hand sanitizer secara mudah agar masyarakat pun dapat membuat sendiri tanpa harus membeli dan dapat dijadikan persediaan sendiri bagi masyarakat. Pembuatan hand sanitizer ini 
ditunjukkan untuk seluruh masyarakat Tegalrejo Rt 1 / Rw 4. Alat dan bahan untuk pembuatan hand sanitizer ini antara lain :

Alat : Sendok. Wadah/mangkuk, dan Botol hand sanitizer.

Bahan : Aloevera dan Alkohol 70\%

Cara Pembuatan :

1. Tuangkan Aloevera pada mangkuk atau wadah secukupnya.

2. Kemudian tuangkan alcohol $70 \%$ pada wadah.

3. Aduk aloevera dan alcohol hingga tercampur rata.

4. Tuangkan hand sanitizer yang sudah jadi pada botol spray yang telah disiapkan.

5. Hand sanitizer yang sudah jadi siap untuk didistribusikan.

Dengan adanya kegiatan ini dihaeapkan masyarakat dapat membuat handsanitizer sendiri dengan bahan-bahan yang mudah ditemukan dan dengan harga yang lebih menghemat biasa daripada harus membeli langsung dan agar masyarakat dapat memabawa sendiri handsanitizer saat keluar rumah.

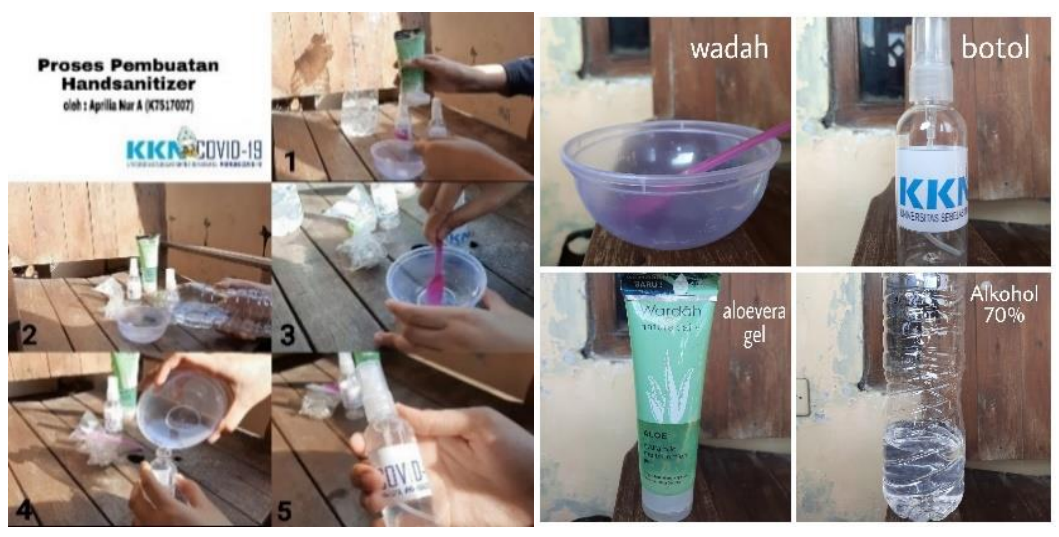

Gambar 5. Cara Pembuatan Handsanitizer (Sumber: Dokumen Pribadi)

\section{KESIMPULAN}

Berdasarkan kegiatan KKN yang dilakukan di Dusun Tegalrejo Rt 1 / Rw 4, Desa Begajah, Kabupaten Sukoharjo disimpulkan bahwa masyarakat ikut berpartisipasi dalam pelaksanaan KKN. Kegiatan sosialisasi mengenai Penerapan Pola Hidup Bersih dan Sehat pada masa pandemi Covid-19 berlangsung lancar dan banyak warga yang antusias degan adanya sosialisasi tersebut. Warga juga 
memberikan tanggapan yang positif terhadap program yang telah dilaksanakan dan menerapkan kegiatan yang telah disampaikan oleh relawan. Kegiatan edukasi dilakukan dengan tetap mematuhi protokol kesehatan yang diwajibkan.

\section{ACKNOWLEDGMENT}

Penulis mengucapkan terimakasih kepada Allah SWT atas nikmat dan karuniaNya yang melimpah. Penulis juga mengucapkan terima kasih kepada UNS Surakarta dan LPPPM UNS selaku penyelenggara Kuliah Kerja Nyata di tahun 2020. Penulis mengucapka terima kasih kepada Bapak Valiant Lukad Perdana Sutrisno, M.Pd selaku Dosen Pembimbing lapangan KKN, penulis juga mengucapkan terimakasih kepada Orang Tua yang telah membantu dalam pelaksanaan KKN Covid-19, dan terimaksih kepada masyarakat Dusun Tegalrejo Rt 1/ Rw 4 yang sudah antusias ikut serta dalam terlaksananya kegiatan KKN ini.

\section{DAFTAR PUSTAKA}

Chan JF, Yuan S, Kok KH dkk. Sekelompok pneumonia keluarga yang terkait dengan novel coronavirus 2019 yang menunjukkan penularan dari orang ke orang: sebuah studi tentang kluster keluarga. Lancet 2020.

Denny, I. M., Putra, C., Regina, M., Tri, A., Yuhari, W., Studi, P., Seni, F., Seni, I., \& Denpasar, I. (2020). Edukasi Covid-19 Melalui Program KKN ISI Denpasar Untuk Mewujudkan Karakter Anak Yang Sadar Kebersihan Di Desa Carangsari. 8(2), 78-83.

Depkes RI. 2007. Krida Bina Perilaku Hidup Bersih dan Sehat. Jakarta.

Guan W, Ni Z, Yu H, dkk. Karakteristik klinis infeksi coronavirus baru 2019 di Cina. pracetak medRxiv diposting online pada 9 Februari 2020

Gunawan, Ary H. 2000. Sosiologi Pendidikan. Jakarta: Rineka Cipta.

Kementerian PUPR RI. (2020). Perilaku Hidup Bersih dan Sehat (PHBS) sebagai Upaya Mencegah Penyebaran COVID-19. Available at: http://plpbm.pu.go.id/v2/posts/Perilaku-Hidup-Bersih-dan-SehatPHBS sebagai-Upaya-Mencegah-Penyebaran-COVID-19 
Koesnadi Hardjasoemantri. 1997. Penegkan Hukum dan Penyelesaian Sengketa dalam UU No. 23 Tahun 1997, Makalah Penataran Hukum Lingkungan. Fakultas Hukum Unair, 6-13 Februari 1997.

Susilo et al. (2020). Coronavirus Disease 2019: Tinjauan Literatur Terkini Coronavirus Disease 2019: Review of Current Literatures', Jurnal Penyakit Dalam Indonesia, 7(1), pp. 45-67.

Tyrrell DA, Bynoe ML. Kultivasi virus dari sebagian besar pasien pilek. Lancet 1966: $1: 76-77$.

WHO. (2020c). Naming the coronavirus disease (COVID-19) and the virus that causes it. Available at: https://www.who.int/emergencies/diseases/novelcoronavirus2019/technical-guidance/naming-the-coronavirus-disease-(covid-2019)-andthe-virus-that-causes-it

WHO. (2020f). WHO Director-General's remarks at the media briefing on2019nCoV on 11 February 2020. Available at: https://www.who.int/dg/speeches/detail/who-director-general-sremarksatthe media-briefing-on-2019-ncov-on-11-february-2020 